\title{
Metisiline Duyarlı ve Dirençli Staphylococcus aureus İzolatlarının Biyofilm Oluşturma Özelliklerinin Konvansiyonel ve Moleküler Yöntemlerle Belirlenmesi
}

\section{Determination of Biofilm Formation Properties of Methicillin Sensitive and Resistant Staphylococcus aureus Isolates by Conventional and Molecular Methods}

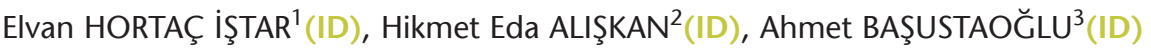 \\ 1 Türkiye Cumhuriyeti Sağlık Bakanlığı Beytepe Murat Erdi Eker Devlet Hastanesi, Merkez Laboratuvarı, Ankara. \\ ${ }^{1}$ Republic of Turkey Minister of Health Beytepe Murat Erdi Eker State Hospital, Central Laboratory, Ankara, Turkey. \\ 2 Başkent Üniversitesi Tıp Fakültesi, Tıbbi Mikrobiyoloji Anabilim Dalı, Adana. \\ 2 Baskent University Faculty of Medicine, Department of Medical Microbiology, Adana, Turkey. \\ ${ }^{3}$ Başkent Üniversitesi Tıp Fakültesi, Tıbbi Mikrobiyoloji Anabilim Dalı, Ankara. \\ ${ }^{3}$ Baskent University Faculty of Medicine, Department of Medical Microbiology, Ankara, Turkey.
}

* Bu çalışma, Başkent Üniversitesi Tıp ve Sağlık Bilimleri Araştırma Kurulu tarafından desteklenmiştir (Proje no: KA16/264).

Makale Atıfı: Hortaç Iştar E, Alışkan HE, Başustaoğlu A. Metisiline duyarlı ve dirençli Staphylococcus aureus izolatlarının biyofilm oluşturma özelliklerinin konvansiyonel ve moleküler yöntemlerle belirlenmesi. Mikrobiyol Bul 2020;54(2):223-234

ÖZ

Biyofilm kaynaklı enfeksiyonlar günümüzde en önemli tedavi başarısızlığı nedenlerinin başında gelmektedir. Biyofilm kaynakı enfeksiyonların en sık etkenlerinden biri Staphylococcus aureus'tur. Biyofilm kaynaklı enfeksiyonlar bakterideki metisilin direnciyle birleştiğinde uygun tedavi protokolü belirlemek son derece güçleşmektedir. Çalışmada farklı klinik örneklerden izole edilmiş metisiline duyarlı ve dirençli S.aureus'ların biyofilm oluşturma potansiyelini gözlemlemek; biyofilm tespitinde kullanılacak güvenilir ve etkin yöntemleri belirlemek amaçlanmıştır. Klinik ve laboratuvar bulgular karşılaştırılarak etken olarak kabul edilen 107 adet yara, 93 adet kan ve kateter örneğinden izole edilmiş toplam 200 S.aureus izolatı (100 adet metisiline dirençli, 100 adet metisiline duyarlı) çalışmaya dahil edilmiştir. Metisilin duyarlılığının tespitinde otomatize sistem ile elde edilen oksasilin minimum inhibitör konsantrasyonu değeri ve sefoksitin disk difüzyon yöntemleri birlikte değerlendirilmiştir. Bakterilerin biyofilm oluşumu modifiye Christensen (MC), MTT, BioTimer ve Kongo kırmızısı agar (KKA) yöntemleri ile incelenmiş, ayrıca biyofilm oluşumundan sorumlu ica operonu varlığı polimeraz zincir reaksiyonu (PCR) ile araştırılmıştır. MC, MTT ve BioTimer yöntemlerinin tümünde metisiline dirençli izolatların duyarlı izolatlara göre daha kısa sürede ve yüksek oranda biyofilm oluşturduğu, oluşturdukları biyofilm yapısının daha yoğun olduğu gösterilmiştir. Kan ve yara izolatları arasında biyofilm oluşumu açısından bir fark bulunmamıştır. Konvansiyonel yöntemlerden en duyarlı yöntemin MTT; en özgül yöntemin BioTimer yöntemi olduğu görülmüştür. PCR 
ile icaADBC operonuna ait bir gen bölgesini içeren izolatlarla MC, MTT, BioTimer, KKA yöntemlerine göre biyofilm oluşturan izolatlar arasında anlamlı bir fark gözlenmemiştir. Tespit edilen biyofilm varlığı ile ica pozitifliği arasında yüksek korelasyon bulunduğu, ica gen sayısı arttıkça biyofilm oluşturma eğiliminin arttığı görülmüştür. Metisiline dirençli S.aureus gibi daha virülan izolatların biyofilm oluşturma eğiliminin daha yüksek olduğu ve bu iki direnç mekanizmasının birbirini kaskat şeklinde destekler nitelikte olduğu görülmüştür. ica tespitinin tek başına bile virülan izolatların belirlenmesinde önemli bir ayıraç olabileceği vurgulanmıs, böylece tedavi kararlarının alınmasında, korunma stratejilerinin belirlenmesinde ve biyofilm kaynaklı enfeksiyonlarla mücadelede erken bir belirteç olabileceği görülmüştür. Moleküler yöntemlerin kullanılamadığı durumlarda biyofilm varlığının tespitinde kullanılacak hızlı sonuç veren, kolay uygulanabilir ve güvenilir konvansiyonel yöntemlerin varlığı son derece önem taşımaktadır. Çalışmamızda kullanılan tüm konvansiyonel yöntemler bu açıdan yeterli gözükmektedir. MC ve MTT yöntemleri biyofilm kantitasyonu da yapması açısından ön plana çıkmaktadır. BioTimer yöntemi ise biyofilm varlığının tespitinde kullanılan çok yeni ve dikkat çekici bir testtir. Sonuç olarak kolonizasyon veya enfeksiyon etkeni olarak belirlenen bakterilerin biyofilm oluşturma potansiyelini belirlemek ve girişimsel işlemlerden önce bu bakterilere yönelik gereken tedbirleri almak biyofilm kaynaklı enfeksiyonları ve bunlara bağlı morbidite ve mortaliteyi azaltacaktır.

Anahtar kelimeler: Staphylococcus aureus; biyofilmler; metisilin direnci.

\section{ABSTRACT}

Biofilm-related infections are considered as among the foremost causes of treatment failure nowadays. One of the most common causes of biofilm-related infections is Staphylococcus aureus. It becomes extremely difficult to determine the appropriate treatment protocol while biofilm-related infections are coexisting with bacterial methicillin resistance. The aim of this study was to observe the potential of biofilm formation of methicillin-sensitive and -resistant S.aureus strains isolated from different clinical specimens and to determine reliable and effective methods for biofilm detection. A total of 200 S.aureus strains (100 methicillin-resistant and 100 methicillin-susceptible) isolated from 107 wound, 93 blood and catheter specimens, which were accepted as causative agents, included in the study. In order to determine the methicillin sensitivity, oxacillin minimal inhibitory concentration value obtained by an automated system and cefoxitin disc diffusion method were evaluated together. Biofilm formation was investigated by modified Christensen (MC), MTT, BioTimer and Congo Red Agar (CRA) methods, and the presence of ica operon responsible for biofilm formation was also observed by polymerase chain reaction. It has been shown that methicillin-resistant isolates produce biofilms in a shorter time and higher rate, and their biofilm structure is denser than methicillin-sensitive isolates in all MC, MTT and BioTimer methods. There was no difference between blood and wound isolates in biofilm formation. The most sensitive and specific conventional methods were MTT and BioTimer methods respectively. There was no significant difference between the isolates containing a gene region of $i c a A D B C$ operon and the biofilm forming isolates according to MC, MTT, BioTimer and CCA methods. There was a high correlation between the presence of biofilm and ica positivity, and the tendency to form biofilm augmented as the number of ica genes increased. It has been emphasized that more virulent strains such as methicillin-resistant S.aureus have a higher tendency to form biofilm, and these two resistance mechanisms have been shown to support each other as cascade. ica detection may be an important reagent in itself for the detection of virulent strains, thus detection of the ica presence may be an early marker of treatment decisions, determination of protection strategies, and struggle with biofilm-related infections. In cases where molecular methods are not available, the existence of quick, easy-to-apply and reliable conventional methods to detect biofilm formation is extremely important. All conventional methods used in this study seem to be sufficient in this respect. MC and MTT methods stand out in terms of biofilm quantitation. BioTimer method is a very new and remarkable test used to detect biofilm formation. In conclusion, determining the potential of biofilm formation of colonizing or causative agents and taking essential precautions before interventional procedures will decrease biofilm related infections and related morbidity and mortality.

Keywords: Staphylococcus aureus; biofilms; methicillin resistance. 


\section{Giriş̧}

Günümüzde tüm dünyada hastane ve toplum kaynaklı enfeksiyonların başında gelen etkenlerden biri olan Staphylococcus aureus birçok lokal ve sistemik enfeksiyonun sebebidir. Stafilokok enfeksiyonlarının patogenezinde toksin ve ekstraselüler enzim üretimi, antibiyotik direnci ve yabancı cisimlerin yüzeyine yapışarak bu yüzeylerde biyofilm oluşumu rol oynar. Özellikle hastane kaynaklı enfeksiyonlarda mikroorganizmanın vücut içine yerleştirilen malzemelere yapışması biyofilm kaynaklı enfeksiyon patogenezinde ilk aşamayı oluşturmaktadır ${ }^{1}$.

S.aureus'un insanda deri, sindirim sistemi ve solunum yollarının normal flora üyesi olması ve yüzeylere yapışmasını kolaylaştıran "slime" faktör oluşturabilme yeteneği tüm dünyada toplum ve hastane kökenli patojenler arasında ilk sıralarda yer almasını sağlamıştır².

Biyofilm yapısı ilk keşfedildiği günden bu yana çeşitli şekillerde tanımlansa da tam tanım olarak kendi ürettikleri polisakkarit yapıda ekstraselüler organik matriks içinde gömülü birbirine ve katı bir yüzeye tutunmuş sıkı ağ yapısında, hareketsiz ve birbirleriyle iletişim halinde bir hücre topluluğudur. Gerek büyüme ve gen ekspresyonu gerekse antibiyotik duyarlıı̆̆ı açısından planktonik formlarından farklılaşmış bir yapıdır ve konakta kronik bir enfeksiyon kaynağıdır ${ }^{3}$.

Biyofilm yapısını tespit etmeye yönelik birçok boyama yöntemi, metabolik ve mikroskobik yöntem tanımlanmaya ve standardize edilmeye çalışı Imıştır. S.aureus biyofilmlerinin oluşumundaki temel mekanizma olan polisakkarit interselüler adezin (PIA) sentezinden sorumlu icaADBC operonunu içeren izolatlar da potansiyel birer biyofilm üreticisi olarak tanımlanmaktadır ${ }^{4,5}$.

Bu çalışmada, çeşitli klinik örneklerden elde edilen metisiline dirençli S.aureus (MRSA) ve metisiline duyarlı S.aureus (MSSA) izolatlarının moleküler ve konvansiyonel yöntemlerle biyofilm oluşturma yeteneğinin araştırılması amaçlanmıştır.

\section{GEREÇ ve YÖNTEM}

Bu çalışma, Başkent Üniversitesi Tıp ve Sağlık Bilimleri Araştırma Kurulu onayı ile gerçekleştirildi (Tarih: 11.08.2016 ve Karar no: 26862).

Çalışmaya Ocak 2013-Haziran 2016 tarihleri arasında Başkent Üniversitesi Tıp Fakültesi Hastanesi Klinik Mikrobiyoloji Laboratuvarı'na gönderilen 107 adet yara, 72 adet kan ve 21 adet kateter örneğinden izole edilmiş, konvansiyonel yöntemler ve Phoenix (Becton Dickinson-BD, ABD) otomatize sisteminde tanımlanmış toplam 200 S.aureus izolatı (100 adet MRSA, 100 adet MSSA) dahil edildi. Yara örnekleri klinik bulgular ve Q skoruna göre, kan örnekleri klinik ve laboratuvar bulguları ile etken olarak kabul edilen izolatlardan seçildi. Kateter örnekleri periferik kanda üreme olup olmamasına göre kateter ilişkili kan dolaşım enfeksiyonu olarak değerlendirilen izolatlardan seçildi. Kateter ilişkili kan dolaşım enfeksiyonu olarak tanımlanan hastaların kan kültür örnekleri genetik ve epidemiyolojik tekrarı önlemek amacıyla çalışmaya dahil edilmedi. 
Metisilin duyarlılığının tespitinde Phoenix (Becton Dickinson-BD, ABD) otomatize sisteminde oksasilin minimum inhibitör konsantrasyonu (MiK) değeri $>2 \mathrm{mg} / \mathrm{L}$ olan bakteriler MRSA kabul edildi. Tüm sonuçlar sefoksitin disk difüzyon testi ile doğrulandı ${ }^{6}$.

\section{Modifiye Christensen Yöntemi (MCY) ile Biyofilm Varlığının Saptanması}

Christensen tarafından tanımlanan yöntem çeşitli modifikasyonlarla uygulandı ${ }^{7}$. Doksan altı kuyucuklu mikroplaklarda her bakteri için üçer kuyucuk kullanıldı. Mikroplakların $\% 5$ koyun kanlı agar besiyerinde $37^{\circ} \mathrm{C}^{\prime}$ de 24 saat inkübasyonu sonrası kuyucuklar fosfat tampon solüsyonu (PBS) (AppliChem, Almanya) ile üç defa yıkandı. Fiksasyon için metanol, boyama için \%2'lik kristal viyole kullanıldı. \%95'lik etanol ile kuyucuk taban ve duvarlarındaki boya çözülerek optik dansiteler spektrofotometrik olarak ölçüldü (BioTek Instruments, Inc., ABD) $)^{8,9}$.

\section{MTT Yöntemi ile Biyofilm Varlığının Saptanması}

Iğne kapaklı 96 kuyucuklu mikroplaklarda (Thermo Scientific, Danimarka) inkübasyon aşamasına kadar MCY ile aynı prosedür izlendi. Mikroplaklar orbital çalkalayıcıda $37^{\circ} \mathrm{C}^{\prime} \mathrm{de}$ 24 saat inkübe edildi. Her çalışma öncesi steril PBS ile taze MTT [3-(4,5-dimethylthiazol2-yl)-2,5-diphenyltetrazolium bromide] çözeltisi hazırlandı (Thermo Fisher Scientific, Danimarka). Kuyucuklara eklenerek karanlık ortamda $37^{\circ} \mathrm{C}^{\prime}$ de üç saat inkübe edildi. İnkübasyon sonunda oluşan formazan kristalleri DMSO (Sigma, Fransa) içerisinde çözülerek spektrofotometrik olarak ölçüldü ${ }^{10}$.

Her iki yöntemden elde edilen optik dansite değerlerinin ortalaması kaydedildi ve biyofilm kantitasyonu yapıldı ${ }^{8}$.

\section{BioTimer Yöntemi ile Biyofilm Varlığının Saptanması}

Bakteri sayısı-renk değişim zamanı korelasyon eğrisini çizmek için hazırlanan bakteri süspansiyonu (S.aureus ATCC 6538) BT-PR besiyeri içeren tüplere eklenerek seri dilüsyonları yapıldı. Tüplerin uygun aralıklarla renk değişim kontrolleri sonucunda her bir konsantrasyon için rengin kırmızıdan sarıya döndüğü süre (120-960 dakika) tespit edildi. Her kuyucuktan $10 \mu \mathrm{l}$ alınarak katı besiyerine ekildi. $37^{\circ} \mathrm{C}^{\prime}$ de 24 saat inkübasyon sonrası koloniler sayılarak zaman/bakteri $\log _{10}$ CFU grafiği çizildi ${ }^{11,12}$. Biyofilm deneyleri iğne kapaklı mikroplaklarda gerçekleştirildi. Kuyucuklara $10^{7} \mathrm{cfu} / \mathrm{ml}$ bakteri süspansiyonu eklenerek orbital çalkalayıcıda $37^{\circ} \mathrm{C}^{\prime}$ de 24 saat inkübe edildi. Her bakteri için üçer kuyucuk kullanıldı. İ̆ne kapak steril PBS ile yıkanarak planktonik hücreler uzaklaştırıldı. BT-PR besiyeri dağıtılmış yeni bir mikroplağa kapak kapatıldıktan sonra besiyerindeki dakikalık renk değiş̧imi gözlendi. Oluşturulan eğri kullanılarak, oluşan biyofilmdeki mikroorganizma sayısı hesaplandı ${ }^{11,12}$.

\section{Kongo Kırmızısı Agar (KKA) Yöntemi ile Biyofilm Varlığının Saptanması}

\%5 koyun kanlı agarda üremiş saf kolonilerden KKA besiyerine tek koloni yöntemiyle ekimler yapıldı. Ekim işlemini takiben plaklar $37^{\circ} \mathrm{C}^{\prime} \mathrm{de}$, ardından oda sıcaklığında birer gün inkübasyon sonrası iki ayrı kişi tarafından değerlendirildi. Tek koloni yöntemiyle ekilen bakterilerden koyu kırmızı-siyah veya pürüzlü, kuru koloni oluşturan izolatlar slime 
pozitif; pembe-kırmızı, bordo veya yalnızca orta kısımları koyu renkte koloni oluşturanlar slime negatif olarak değerlendirildi ${ }^{13,14}$.

\section{Polimeraz Zincir Reaksiyonu (PCR) ile Biyofilm Genlerinin Gösterilmesi}

DNA ekstraksiyonu uyumlu izolasyon kitiyle üretici firmanın önerileri doğrultusunda yapıldı (Macherey-Nagel, Almanya). icaA, icaB, icaC ve icaD gen bölgelerinin varlığı literatürde tanımlanmış primer dizileri kullanılarak PCR yöntemi ile araştırıld $\iota^{5,13}$.

Tüm biyofilm deneylerinde S.aureus ATCC 6538 ve Staphylococcus epidermidis ATCC 35984 pozitif, S.aureus ATCC 29213 ve S.epidermidis ATCC 12228 negatif kontrol suşları olarak kullanıldı.

\section{İstatistiksel Analiz}

Sayısal verilerin normal dağılıma uygunluğu Kolmogorov-Smirnov ve Shapiro-Wilk testleri ile kontrol edildi. Normal dağılıma uymayan sayısal verilerin bağımsız gruplar arası karşılaş̧ırmasında Mann-Whitney $U$ testi; bağımlı gruplar arası karşılaştırmada Wilcoxon Signed Rank testi kullanıldı. Nominal değerlerin karşılaştırmasında bağımsız gruplar için ki-kare testi, bağımlı gruplar için McNemar testi uygulandı. p değeri $<0.05$ istatistiksel olarak anlamlı kabul edildi.

\section{BULGULAR}

Yara örneği 107 (\%53.5), kan ve kateter örneği 93 (\%46.5) olmak üzere toplam 200 S.aureus izolatı çalışmaya dahil edilmiştir. Metisiline dirençli 100, metisiline duyarlı 100 izolat saptanmıştır.

MCY'de izolatların 83 (\%41.5)'ü biyofilm oluştururken, 117 (\%58.5)'si oluşturmamıştır (Tablo I). Biyofilm oluşturan bakterilerin 62 (\%31)'sinin zayıf, 18 (\%9)'inin orta, 3 (\%1.5)'ünün kuvvetli derecede biyofilm oluşturduğu gözlenmiştir. Biyofilm oluşturan örneklerin 49 (\%59)’u MRSA, 34 (\%41)'ü ise MSSA olarak belirlenmiştir. Bu sonuçlara göre, MRSA izolatlarının biyofilm oluşturma oranı MSSA izolatlarına göre anlamlı yüksek bulunmuştur $(p=0.031)$. Kuvvetli derecede biyofilm oluşturan 3 bakteri MRSA, orta derecede biyofilm oluşturan 18 bakterinin 2'si MSSA olarak saptanmıştır. Yara izolatlarının kan ve kateter izolatlarına oranla daha yüksek oranda biyofilm oluşturduğu gözlenmiştir $(p=0.029)$.

\begin{tabular}{|lcccccc}
\multicolumn{6}{l}{ Tablo I. Staphylococcus aureus izolatlarının Biyofilm Oluşturma Yetenekleri } \\
\hline \multicolumn{7}{c}{ Biyofilm pozitif } \\
\hline MRSA (n) & MSSA (n) & Toplam n (\%) & MRSA (n) & MSSA (n) & Toplam n (\%) \\
\hline MCY & 49 & 34 & $83(41.5)$ & 51 & 66 & $117(58.5)$ \\
MTT & 47 & 27 & $74(37)$ & 53 & 73 & $126(63)$ \\
BioTimer & 48 & 40 & $88(44)$ & 52 & 60 & $112(56)$ \\
KKA & 41 & 51 & $92(46)$ & 59 & 49 & $108(54)$ \\
\hline
\end{tabular}

MCY: Modifiye Christensen yöntemi, MTT: MTT yöntemi, BioTimer: BioTimer yöntemi, KKA: Kongo kırmızısı agar, MRSA: Metisiline dirençli S.auerus, MSSA: Metisiline duyarlı S.aureus. 
MTT yöntemine göre izolatların 74 (\%37)'ü biyofilm pozitif, 126 (\%63)'sı ise biyofilm negatif bulunmuştur (Tablo I). Biyofilm oluşturan bakterilerden 56 (\%28)'sı zayıf, 17 (\%8.5)'si orta, 1 (\%0.5)'i ise kuvvetli derecede biyofilm oluşturmuştur. Biyofilm oluşturan örneklerin 47 (\%63.5)'si MRSA, 27 (\%36.5)'si MSSA olarak belirlenmiştir. MTT yönteminde MRSA izolatlarının biyofilm oluşturma oranı MSSA izolatlarına göre anlamlı yüksek bulunmuştur ( $p=0.003$ ). Kuvvetli ve orta derecede biyofilm oluşturan 17 bakteriden 16'sı MRSA olarak saptanmıştır. Kan ve kateter izolatları ile yara izolatları arasında biyofilm oluşumu bakımından istatistiksel olarak anlamlı bir fark gözlenmemiştir ( $p>0.05)$.

BioTimer yöntemine göre çalışmaya alınan izolatlardan 88 (\%44)'i biyofilm oluştururken, 112 (\%56)'sinde biyofilm oluşumu gözlenmemiştir (Tablo I). Biyofilm pozitif örneklerden 40 (\%45.5)’ ıSSA iken, 48 (\%54.5)'i MRSA olarak belirlenmiştir. Metisiline dirençli izolatların duyarlı izolatlara göre daha yoğun ve kısa sürede biyofilm oluşturduğu görülmüştür ( $p=0.011)$. Yara izolatlarının kan izolatlarına göre daha yüksek oranda biyofilm oluşturduğu gözlenmiştir $(p=0.005)$.

KKA'da 108 (\%54) izolat slime oluşturmazken, 92 (\%46) izolatın oluşturduğu görülmüştür (Tablo I). Slime pozitif izolatlardan 51 (\%55.4)'inin MSSA, 41 (\%44.6)'inin MRSA olduğu tespit edilmiştir. Hem MRSA ve MSSA izolatları hem de kan ve yara izolatları arasında slime oluşumu bakımından anlamlı bir fark görülmemiştir.

icaADBC gen bölgelerinin varlığına bakıldığında 71 (\%35.5) izolatta icaA, 13 (\%6.5) izolatta icaD, 2 (\%1) izolatta icaB ve icaC pozitifliği görülmüştür. Tek başına icaA pozitifliği gösteren bakteri sayısı 62 (\%31), hem icaA hem de icaD gen bölgelerini birlikte içeren bakteri sayısı ise 9 (\%4.5) olarak tespit edilmiştir. Her dört gen bölgesini birlikte içeren 2 (\%1) bakteri olduğu görülmüştür. Tek başına icaD gen bölgesi içeren 4 (\%2) izolat tespit edilirken, yalnızca icaB veya icaC gen bölgelerini bulunduran hiçbir izolat bulunmamıştır (Şekil 1). icaB ve icaC pozitifliği gösteren her iki izolat da MRSA olarak belirlenmiştir.

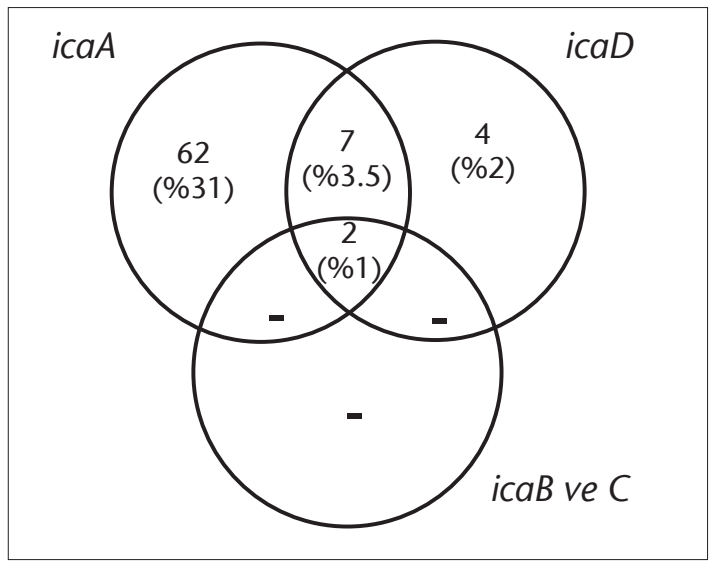

Şekil 1. Staphylococcus aureus izolatlarındaki icaADBC pozitiflikleri. 
MRSA ve MSSA izolatları icaADBC operonu barındırma yönünden karşılaştırıldığında metisiline dirençli izolatların duyarlı izolatlara göre anlamlı derecede ve yüksek oranda ica gen bölgesi içerdiği gözlenmiştir $(p<0.05)$.

icaADBC pozitifliği bakımından kan-kateter ve yara izolatları arasında anlamlı bir farklılık gözlenmemiştir ( $\mathrm{p}>0.05)$.

MCY ile ica varlığı karşılaştırıldığında icaADBC operonuna ait herhangi bir gen bölgesini bulunduran 75 bakteriden 13 (\%17.3)'ünün biyofilm oluşturmadığı, 62 (\%82.6)'sinin ise çeşitli derecelerde biyofilm oluşturduğu gözlenmiştir. PCR ile icaADBC operonuna ait bir gen bölgesini içeren izolatlarla $\mathrm{MCY}^{\prime}$ ye göre biyofilm oluşturan izolatlar arasında anlamlı bir fark gözlenmemiştir ( $p>0.05$ ).

ica bulundurduğu bilinen 75 bakteriden 19 (\%25.3)'u MTT yönteminde biyofilm oluşturmazken, 56 (\%74.7)'sı çeşitli derecelerde biyofilm oluşturmuştur. PCR'de ica pozitifliği saptanan izolatlar ile MTT yönteminde biyofilm oluşturduğu gözlenen izolatlar arasında anlamlı bir fark olmadığı gözlenmiştir ( $p>0.05)$.

BioTimer yönteminde ica pozitifliği gösteren 75 izolattan yalnızca 10 (\%13.3)'u biyofilm oluşturmazken, 65 (\%86.7) izolat çeşitli derecede biyofilm oluşturmuştur. PCR'de ica pozitifliği saptanan izolatlar ile BioTimer yöntemine göre biyofilm oluşturduğu gözlenen izolatlar arasında anlamlı bir fark olmadığı gözlenmiştir ( $p>0.05)$.

ica pozitifliği gösteren 75 izolattan 20 (\%26.7)'si KKA'da slime oluşturmazken, 55 (\%73.3) izolatta slime yapısına rastlanmıştır. PCR'de ica pozitifliği saptanan izolatlar ile KKA'da slime oluşturduğu gözlenen izolatlar arasında anlamlı bir fark olmadığı gözlenmiştir ( $p>0.05)$.

PCR'de herhangi bir ica gen bölgesi varlığı altın standart kabul edilerek tüm konvansiyonel yöntemlerin duyarlılıkları yukarıda bahsedilen sırayla \%82.2, \%84, \%81.6, \%68.8; özgüllükleri \%81.3, \%72, \%86.7, \%70.7 olarak hesaplanmıştır. En duyarlı yöntemin MTT, en özgül yöntemin BioTimer yöntemi olduğu tespit edilmiştir.

Biyofilm formasyonunun kantitatif değerlendirilmesinde icaADBC operonundaki gen bölgelerinden iki ve daha fazlasının birlikte pozitifliğinin oluşan biyofilm yapısını anlamlı derecede kuvvetlendirdiği görülmüştür $(p<0.05)$. Tek bir ica lokusu içeren izolatların hiç ica içermeyenlere göre anlamlı düzeyde kuvvetli biyofilm oluşturmasının yanı sıra, iki ve daha fazla ica lokusu içeren izolatların da tek bir ica pozitifliği gösteren izolatlara göre anlamlı derecede kuvvetli biyofilm oluşturduğu gözlenmiştir $(p<0.05)$. Pozitif ica gen sayısının artışına paralel olarak biyofilm yapısının da giderek daha kuvvetli pozitiflik verdiği gözlenmiştir.

Yalnız bir ica pozitif olan ve birden fazla ica pozitifliği gösteren izolatlarda konvansiyonel yöntemlerin biyofilm varlığını tespit edebilme düzeyleri araştırıldığında kullanılan tüm yöntemlerin birden fazla ica pozitifliği gösteren izolatlarda anlamlı derecede yüksek pozitiflik verdiği görülmüştür $(p<0.001)$. 


\section{TARTIŞMA}

Deri ve yumuşak doku enfeksiyonu etkenleri içerisinde S.aureus öne çıkan patojenlerden biridir. Deri ve yumuşak doku enfeksiyonu etkeni olarak S.aureus'un Fransa, Almanya ve İtalya'da en sık, Amerika Birleşik Devletleri ve İspanya'da ikinci en sık etken olarak görüldüğü; Kuzey ve Güney Amerika ile Avrupa genelinde ise ilk sırada yer aldığı bildirilmiştir. Uzak Doğuda tüm patojenler içerisinde \%42.3 ile en sık enfeksiyon etkeni olduğu tespit edilmiştir ${ }^{15-17}$.

Hastanede yatan hastalarda intravasküler kateter kullanımı \%50-60 oranındadır ve gelişen bakteremilerin yaklaşık \%40'ı kateter kaynaklıdır ${ }^{18}$. Kateter yüzeyi biyofilm oluşumunun ilk basamağı olan yüzeye tutunmasını kolaylaştırarak damar içerisinde hızla platelet ve doku proteinleri tarafından kaplanır; bakteriyel yüzey proteinlerinin tutunması $\operatorname{artar}^{19}$. S.aureus kaynaklı bakteremilerde kateter kullanımı etyolojide büyük önem taşımaktadır.

Çalışmamızda S.aureus'un en sık enfeksiyon etkeni olduğu deri ve yumuşak doku örnekleriyle, biyofilm oluşumunun bir göstergesi olan kateter kültür örnekleri ve çeşitli nedenlerle S.aureus bakteremisi olan hastaların kan kültür örnekleri kullanılmıştır.

Kan ve yara izolatları arasında ica operonu barındırma yönünden bir farklılık olmadığı tespit edilmiştir. Türkiye'de kan ve sağlıklı erişkinlerin el kültürlerinden izole edilen stafilokoklarda yapılan bir çalışmada iki grup arasında biyofilm oluşumu açısından bir fark saptanmamıştır ${ }^{20}$. Burun ve kan kültürlerinden izole edilen S.aureus izolatlarının karşılaştıııldığı bir diğer çalışmada iki grup arasında anlamlı bir fark olmadığı gözlenmiştir ${ }^{21}$. Özellikle kronik ülseratif lezyonlarda S.aureus biyofilmlerinin önemli rolü olduğu, kronik yara ve ülserlerin \%88-93.5'inde S.aureus ürediği gösterilmiştir ${ }^{4}$. Bu durum S.aureus'un kolaylıkla dissemine olabilme özelliği de göz önünde bulundurulduğunda yara izolatları ile bakteremi etkeni olan izolatların biyofilm oluşturma karakteristiği açısından farklılık göstermemesini açıklamaktadır.

Kullandığımız biyofilm tespit yöntemlerinin tümünde MRSA izolatlarının ica bulundurma oranı, oluşturduğu biyofilm miktarı, biyofilm oluşturma süresi ve biyofilm yapısının yoğunluğu MSSA izolatlarına göre yüksek bulunmuştur. Yalnızca KKA'da slime oluşumu bakımından fark görülmemiştir. Bu sonuçlar biyofilm oluşumu-metisilin direnci ilişkisini inceleyen diğer çalışmaları destekler niteliktedir ${ }^{22,23}$.

MRSA kökenli biyofilm yapılarının daha kalın olmasıyla alt katmanlardaki hücreler ilacın penetrasyon yetersizliğinden dolayı sürekli düşük antibiyotik konsantrasyonuna maruz kalır ve bakterinin direnç kazanma ihtimali artar. Antibiyoterapi sırasında alt katmanlardaki hücrelerin ek biyofilm tabakası geliştirme olasılığı da vardır²2. Ayrıca bazı antibiyotiklerin subinhibitör konsantrasyonlarının ica ekspresyonunu indüklediği gösterilmiştir ${ }^{24}$. Stafilokoklarda antibiyotik direnci-biyofilm oluşumu ilişkisi değerlendirildiğinde her iki sistemin de birbirlerini kaskat şeklinde tetiklediği söylenebilir.

ica varlığıyla MCY, MTT ve BioTimer yöntemlerindeki biyofilm pozitifliği arasında anlamlı bir korelasyon görülmüştür. Ayrıca ica gen bölgesi sayısı arttıkça oluşan biyofilm 
yapısının anlamlı derecede kuvvetlendiği görülmüştür. Çalışmalar MCY'nin icaADBC pozitifliğiyle yüksek korelasyon gösterdiğini; ica gen bölgesi sayısı arttıkça oluşan biyofilm yapısının anlamlı derecede kuvvetlendiğini ortaya koymuştur ${ }^{9,21,25}$.

MTT yönteminde bir tetrazolyum tuzu olan MTT'nin biyofilmdeki canlı bakterilerin dehidrogenaz enzimleriyle formazana indirgenmesi ölçülmektedir ${ }^{10}$. PCR'de ica pozitifliği altın standart kabul edilerek değerlendirildiğinde en duyarlı biyofilm tespit yönteminin \%84 ile MTT yöntemi olduğu tespit edilmiştir. Literatürde MTT yönteminin biyofilmlerdeki bakteriyel popülasyonun büyüklüğünü belirlemede başarılı, biyofilm inhibisyon deneyleri ve antibakteriyel ajanların etkinliğinin araştırılmasında hızlı ve güvenilir bir yöntem olduğundan bahsedilmiş ve spektrofotometride ölçülen formazan konsantrasyonuyla bakteri koloni sayısı arasında mükemmel derecede uyum olduğu gösterilmiştir ${ }^{26}$.

BioTimer yöntemi bakterileri doğrudan biyofilm yapısının içinde sayan, tekrarlanabilir ve güvenilir ilk yöntemdir ${ }^{10,12}$. Çalışmamızda değerlendirilen yöntemler içerisinde en özgül yöntem olduğu görülmüştür (\%86.7). Doğrudan biyofilmdeki canlı hücreler tespit edildiğinden testin yanlış pozitiflik verme olasılığı çok düşüktür. BioTimer yöntemi biyofilm inhibisyon testlerinde ve nano partiküllerin mikrobiyolojik kalitesinin tespitinde kullanılabilme özelliğine sahip; biyofilm formasyonu oluşturmuş bakterileri saymada bir "biyosensör" olarak tanımlanmaktadır. Bakterisit konsantrasyonlarını belirlemekle kalmayıp dirençli bakteri sayısını da gösteren ilk yöntemdir ${ }^{27}$. Gelişmiş teknolojik cihazlara ve sonikasyon gibi işlemlere gereksinim duyulmaması yöntemin avantajları arasındadır ${ }^{28}$. Şimdilik bu yöntemin asıl dezavantajı güvenilirliği, verimliliği ve duyarlıı̆̆ını referans yöntemlerle karşılaştırma imkanını kısıtlayan geçerli bir referans yönteminin eksikliğidir. Literatürde bizim çalışmamızdaki gibi diğer konvansiyonel ve moleküler yöntemlerle BioTimer yönteminin uyumunu karşılaştıran yayın bulunmamaktadır.

KKA yönteminin kullanıldığı birçok çalışmada biyofilm ve slime kavramları birbirinin yerine kullanılsa da biyofilm tam tanım olarak matriks içine gömülü çok katlı hücre tabakası anlamına geldiğinden çalışmamızda KKA yöntemi ile gözlenen patern biyofilm değil slime yapısı olarak tanımlanmıştır. Kongo kırmızısı bakterilerdeki slime faktörü ile birleşerek koyu bir renk oluşturmaktadır ${ }^{14}$. S.aureus'un diğer stafilokoklara göre daha yavaş slime ürettiği bilindiğinden çalışmamızda 48. saat okumaları esas alınmıştır ${ }^{13,25}$. MRSA ve MSSA izolatları slime üretimi yönünden karşılaştırıldığında iki grup arasında anlamlı bir fark bulunmamıştır. Çalışmamızda iki ayrı gözlemci tarafından ayrı ayrı değerlendirme yapılsa da test sonuçlarının nispeten subjektif yorumlanabilmesi, özellikle MRSA kolonilerinin mor, kahverengi, bordo, koyu ve açık kırmızı gibi karar vermesi güç renklerde koloniler oluşturması nedeniyle iki grup arasında bir fark görülmediği düşünülmüştür. MRSA izolatları KKA plağında MSSA izolatlarına göre daha belirsiz ve karar vermesi güç koloniler oluşturduğundan yöntemin \%13.9 gibi yüksek bir oranda çelişkili sonuçlar verdiğinden bahsedilmiştir ${ }^{29}$.

Literatürde yer alan çalışmalar, sonuçlarımızla uyumlu olarak ica varlığıyla KKA'daki slime oluşumunun paralelliğini göstermiştir ${ }^{13,25}$. Her ne kadar slime biyofilm kavramını 
tam olarak açıklamasa da moleküler testlerle tanının mümkün olmadığı ve çok basamaklı, özel hazırlık gerektiren yöntemlerin kullanılamadığı durumlarda KKA yöntemi slime oluşumunu tespit etme bakımından kullanışlı, kolay uygulanabilir ve ucuz bir yöntem olarak gözükmektedir.

Kullanılan tüm konvansiyonel yöntemlerde istatistiksel olarak anlamlı olmasa da, ica negatif olduğu halde biyofilm oluşturduğu gözlenen izolatlara rastlanmıştır. BioTimer ve KKA yöntemlerindeki subjektif yorumlama böyle bir sonuca neden olmuş olabilir; ancak daha muhtemel teori ica gen regülasyonu ile açıklanabilir.

Tüm mikrobiyal enfeksiyonların yaklaşık \%65'i biyofilm kaynaklıdır ve bu oran nozokomiyal enfeksiyonlarda çok daha yüksektir ${ }^{3}$. Klinik izolatların saprofitik stafilokoklara göre daha yüksek oranda ica gen bölgesi içerdiği de bilindiğinden ica varlığının araştırılması virülan-nonvirülan izolatların belirlenmesinde tek başına bile önemli bir belirteç$\operatorname{tir}^{9,13}$. Özellikle hastanede yatan hastalardan alınan örneklerde kültürde kolonizasyon veya enfeksiyon etkeni olarak tespit edilen bakterilerin biyofilm oluşturma potansiyelini belirlemek ve bu bakterilerin girişimsel işlemler öncesinde planktonik formlarını elimine edici girişimlerde bulunmak biyofilm kaynaklı enfeksiyon sayısını, dolayısıyla buna bağlı morbidite ve mortalite oranlarını düşürecektir.

Klinik örneklerde üreyen S.aureus izolatlarındaki ica varlığının tespiti tedavi seçenekleri ve korunma önlemleri için alınan kararlara yön verebilir. ica lokusundaki gen bölgelerinin işlevini, klinik önemini ve bulunma sıklığını bilmek tıbbi ekipmanları kolonize eden ve çeşitli biyofilm kaynaklı enfeksiyonlara yol açan bakterilerle mücadelede yeni stratejilerin geliştirilmesini destekleyecektir.

\section{TEŞEKKÜR}

İzolatların teminindeki yardımları için Başkent Üniversitesi Tıp Fakültesi Enfeksiyon Hastalıkları ve Klinik Mikrobiyoloji Anabilim Dalı öğretim üyeleri Prof. Dr. Ayşe Hande Arslan ve Prof. Dr. Özlem Kurt Azap'a, PCR deneyleri başta olmak üzere verdiği tüm destek için TOBB ETÜ Tıp Fakültesi Tıbbi Mikrobiyoloji Anabilim Dalı öğretim üyesi Prof. Dr. Jülide Sedef Göçmen'e teşekkür ederiz.

\section{ÇIKAR ÇATIŞMASI}

Yazarlar bu makale ile ilgili herhangi bir çıkar çatışması bildirmemişlerdir.

\section{KAYNAKLAR}

1. Sudağidan M, Cavuşoğlu C, Bacakoğlu F. Biyomalzeme yüzeylerinden izole edilen metisiline dirençli Staphylococcus aureus suşlarında virulans genlerinin araştırılması. Mikrobiyol Bul 2008; 42(1): 29-39.

2. Tong SY, Davis JS, Eichenberger E, Holland TL, Fowler VG Jr. Staphylococcus aureus infections: epidemiology, pathophysiology, clinical manifestations, and management. Clin Microbiol Rev 2015; 28(3): 603-61.

3. Altun HU, Şener B. Biyofilm infeksiyonları ve antibiyotik direnci. Hacettepe Tıp Dergisi 2008; 39: 82-8.

4. Archer NK, Mazaitis MJ, Costerton JW, Leid JG, Powers ME, Shirtliff ME. Staphylococcus aureus biofilms: properties, regulation and roles in human disease. Virulence $2011 ; 2(5)$ : 445-59. 
5. Diemond-Hernandez B, Solorzano-Santos F, Leanos-Miranda B, Peregrino-Bejarano L, Miranda-Novales G. Production of icaADBC-encoded polysaccharide intercellular adhesin and therapeutic failure in pediatric patients with staphylococcal device-related infections. BMC Infect Dis 2010; 10: 68.

6. The European Committee on Antimicrobial Susceptibility Testing. Breakpoint tables for interpretation of MICs and zone diameters. Version 8.0, 2018.

7. Christensen GD, Simpson WA, Younger JJ, Baddour LM, Barrett FF, Melton DM, et al. Adherence of coagulase-negative staphylococci to plastic tissue cultureplates: a quantitative model for the adherence of staphylococci to medical devices. J Clin Microbiol 1985; 22(6): 996-1006.

8. Stepanovic S, Vukovic D, Hola V, Di Bonaventura G, Djukic S, Cirkovic I, et al. Quantification of biofilm in microtiter plates: overview of testing conditions and practical recommendations for assessment of biofilm production by staphylococci. APMIS 2007; 115(8): 891-9.

9. Gad GF, El-Feky MA, El-Rehewy MS, Hassan MA, Abolella H, El-Baky RM. Detection of icaA, icaD genes and biofilm production by Staphylococcus aureus and Staphylococcus epidermidis isolated from urinary tract catheterized patients. J Infect Dev Ctries 2009; 3(5): 342-51.

10. Saising J, Dube L, Ziebandt AK, Voravuthikunchai SP, Nega M, Götz F. Activity of gallidermin on Staphylococcus aureus and Staphylococcus epidermidis biofilms. Antimicrob Agents Chemother 2012; 56(11): 5804-10.

11. Güven N, Kaynak Onurdağ F. İlaç, kozmetik ve gıda ürünlerinde kullanılan bazı koruyucuların antimikrobiyal ve antibiyofilm etkisinin araştırılması. Mikrobiyol Bul 2014; 48(1): 94-105.

12. Pantenella F, Valenti P, Frioni A, Natalizi T, Coltella L, Berlutti F. BioTimer Assay, a new method for counting Staphylococcus spp. in biofilm without sample manipulation applied to evaluate antibiotic susceptibility of biofilm. J Microbiol Methods 2008; 75(3): 478-84.

13. Vasudevan P, Nair MK, Annamalai T, Venkitanarayanan KS. Phenotypic and genotypic characterization of bovine mastitis isolates of Staphylococcus aureus for biofilm formation. Vet Microbiol 2003; 92(1-2): 179-85.

14. Freeman DJ, Falkiner FR, Keane CT. New method for detecting slime production by coagulase negative staphylococci. J Clin Pathol 1989; 42(8): 872-4.

15. Moreillon P, Que Y, Glauser MP. Staphylococcus aureus (Including Staphylococcal Toxic Shock), pp: 2321 51. In: Mandell GL, Bennett JE, Dolin R (eds), Mandell, Douglas and Bennett's Principles and Practice of Infectious Diseases. 2005, $6^{\text {th }}$ ed. Churchill Livingstone, Philadelphia.

16. Moet GJ, Jones RN, Biedenbach DJ, Stilwell MG, Fritsche TR. Contemporary causes of skin and soft tissue infections in North America, Latin America, and Europe: Report from the SENTRY Antimicrobial Surveillance Program (1998-2004). Diagn Microbiol Infect Dis 2007; 57(1): 7-13.

17. Ho PL, Chuang SK, Choi YF, Lee RA, Lit ACH, Ng TK, et al. Community-associated methicillin-resistant and methicillin-sensitive Staphylococcus aureus: skin and soft tissue infections in Hong Kong. Diagn Microbiol Infect Dis 2008; 61(3): 245-50.

18. Qu Y, Daley AJ, Istivan TS, Garland SM, Deighton MA. Antibiotic susceptibility of coagulase-negative staphylococci isolated from very low birth weight babies: comprehensive comparisons of bacteria at different stages of biofilm formation. Ann Clin Microbiol Antimicrob 2010; 9(16): 1-12.

19. Lindsay D, Von Holy A. Bacterial biofilms within the clinical setting: what healthcare professionals should know. J Hosp Infect 2006; 64(4): 313-25.

20. Göçmen JS, Hortaç İştar E, Çökeliler D, Mutlu M, Kaleli Can G, Alparslan S, et al. Kan ve el kültüründen izole edilen koagülaz-negatif stafilokok izolatlarının biyofilm oluşumunun plazma polimerizasyon tekniği ile kaplanmış mikroplaklarda incelenmesi: deneysel model. FLORA 2017; 22(4): 166-74.

21. Knobloch JK, Horstkotte MA, Rohde H, Mack D. Evaluation of different detection methods of biofilm formation in Staphylococcus aureus. Med Microbiol Immunol 2002; 191(2): 101-6.

22. McCarthy H, Rudkin JK, Black NS, Gallagher L, O'Neill E, O'Gara JP. Methicillin resistance and the biofilm phenotype in Staphylococcus aureus. Front Cell Infect Microbiol 2015; 28(5): 1-9.

23. Houston P, Rowe SE, Pozzi C, Waters EM, O'Gara JP. Essential role for the major autolysin in the fibronectinbinding protein-mediated Staphylococcus aureus biofilm phenotype. Infect Immun 2011; 79(3): 1153-65. 
24. Wang Q, Sun FJ, Liu Y, Xiong LR, Xie LL, Xia PY. Enhancement of biofilm formation by subinhibitory concentrations of macrolides in icaADBC-positive and -negative clinical isolates of Staphylococcus epidermidis. Antimicrob Agents Chemother 2010; 54(6): 2707-11.

25. Arciola CR, Baldassarri L, Montanaro L. Presence of icaA and icaD genes and slime production in a collection of staphylococcal strains from catheter-associated infections. J Clin Microbiol 2001; 39(6): 2151-6.

26. Traba C, Liang JF. Susceptibility of Staphylococcus aureus biofilms to reactive discharge gases. Biofouling $2011 ; 27(7):$ 763-72.

27. Welch K, Cai Y, Stromme M. A method for quantitative determination of biofilm viability. J Funct Biomater 2012; 3(2): 418-31.

28. Kaynak Onurdağ F, Ozgen S, Abbasoğlu U, Gürcan IS. Candida türlerinin biyofilm oluşturan ve planktonik formlarının antifungal ajanlara karşı in vitro duyarlılıklarının araştırılmasında iki farklı yöntemin karşılaştırılması. Mikrobiyol Bul 2010; 44(4): 619-31.

29. Grinholc M, Wegrzyn G, Kurlenda J. Evaluation of biofilm production and prevalence of the icaD gene in methicilin-resistant and methicilin-susceptible Staphylococcus aureus strains isolated from patients with nosocomial infections and carriers. FEMS Immunol Med Microbiol 2007; 50(3): 375-9. 